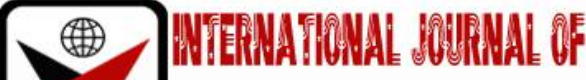

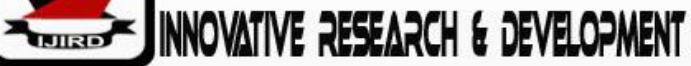

ISSN 2278-0211 (Online)

\section{Evaluative Language in Nigerian Political Speeches: An Appraisal Analysis of John Kayode Fayemi Inauguration Speech as Ekiti State Governor in 2018}

\author{
Dr. Moses Olusanya Ayoola \\ Lecturer, Department of English, College of Education, Ikere-Ekiti, Nigeria
}

\begin{abstract}
:
Political speech is a kind of speech that always carries the emotion of the speaker as well as reflecting the sociopolitical context of the speaker. This paper is an attempt of linguistic appraisal analysis of political speech in Nigeria. The study aims to provide an exploration of the attitudinal choices and meaning in the inauguration speech of Dr. John Kayode Fayemi on October, 2018 as governor of Ekiti state in Nigeria. The theoretical framework employed for the analysis in the study is the appraisal theory of Martin and White (2005) which is an extension and elaboration on the interpersonal Metafunction of Hallidayan Systemic Functional Linguistics (SFL). The study finds out that the speech is however, full of both invoked and inscribed attitudinal meanings that reflect the speaker's position on and reaction to the economic and socio-political situation of the state as well as the experience of the citizens in the past four years. Attitude in the speech are deployed in the construal of three main semantic domains, of affect, judgment, and appreciation, The study concludes that Attitude (Affect, Judgment and Appreciation) in the speech is an effective strategy by the speaker for evaluating the socio-economic reality of Ekiti state and the performance of previous government; positioning his audience (Ekiti people) and for negotiating solidarity with them by making them to share his feelings as well as appreciating the human capital resources of the state.
\end{abstract}

Keywords: Political speech, appraisal, attitude, appreciation, judgment, affect

\section{Introduction}

Political speeches in Nigeria are a peculiar type of speech because of its relevance to social and political life of the people. Bearing in mind its characteristics and purpose, political speech is considered as a form of exposition which functions to advance an argument or propose a view point about a political matter, and socio-economic state of the country. Therefore, there is a need to embark upon a linguistic exploration of political speech in Nigeria, in order to gain insight into how the politicians use language to express their view points and reflect the political context of the speech through the various choices of expression.

In recent times, the interest of linguists has been on the way politicians use language to create certain world view. The politicians through their lexical and syntactic choices relate their world view to their audience for the purpose of persuading the voters or canvassing the masses to support a policy or opinion. According to Thorne (2008:420) in analysing political language, "it is possible to identify occasions when politicians try to subvert or obscure issues, evade questions or arouse audience emotions". Thus, Politicians can influence our views and reasoning about events and sociopolitical issues around through manipulative use of language.

For a speech to be effective and persuasive enough depends on the speaker's ability to use language appropriately and if the function of political speech is to make people believe in a certain world view and to persuade them to support a certain course of action, then it is worth studying from the perspective of appraisal in order to evaluate the commitment of the speakers to their assertions. This study therefore will analyse the inauguration speech of John Kayode Fayemi on $18^{\text {th }}$ October 2018 as the governor of Ekiti state for the second time. Ekiti state is a peculiar state in Nigeria, known for her homogeneity and unique political decisions and crisis. Fayemi was governor of the state between 2010 and 2014 ; he was defeated in 2014 by the former ousted governor, Ayodele Fayose in a controversial election regarded to be crooked by some elites but adjudged to be free and fair by the majority and the international organisation. Fayemi contested the election in 2018 and won the mandate he was denied in 2014. Hence, he tagged his inauguration speech "Reclaiming the Land of Honour". The appraisal analysis of this speech will reveal the attitude of Fayemi to the political circumstances that led to his defeat in 2014 and his victory again in 2018 as well as his response to the administrative style of Fayose who for four years would always make the headlines of newspapers for his stunt criticism of the president (Muhammadu Buhari) and Federal government. 


\section{Literature Review}

The study of the language use in political texts is catching the attention of scholars all over the world. Many studies, within and outside Nigeria had been carried out the language of political speech taking different linguistic approaches. Opeibi (2006) provides a structural and functional description of the significant features of language use in the political texts with the primary aim of demonstrating the emerging trend in an L2 context. In his analysis, he uses data set taken from selected Nigerian national newspapers' adverts produced during the general elections in Nigeria. Ayoola (2015) investigated the linguistic choices with which the politicians attempt to persuade the masses to vote for the candidates of their different political parties. The study took Systemic Functional Grammar (SFG) as a theoretical approach to find out the type of propositions made in the advertisements through the systems of mood and modality; the belief and the ideology of the political parties/candidates as revealed by the linguistic choices; the impact of the arrangement of words in the understanding and the interpretation of the Political advertisement through the system of theme and the contextual factors that determine the choices made in the texts.

Ademilokun (2015) analysed the construal of attitudinal meaning by President Buhari in his inaugural speech of May 2015. The analysis revealed that the different aspects of attitude as a domain of appraisal theory manifest in the speech as the speaker expressed affectual meanings, expressed judgments and demonstrated appreciations in the speech. Ayeomoni and Akinkuolere (2012) is a pragmatic analysis of victory and inaugural Speeches of President Musa Yar'Adua. The study focused on the locutionary, illocutionary and perlocutionary acts of the speeches, using the speech act theory of Austin (1962) and Searle (1969) as theoretical framework with a view to determining the predominant pattern of pragmatic moves in the speech.

Obviously, a lot of these works had been carried out from the perspective of pragmatics, discourse analysis, stylistics while only few took the approach of appraisal theory. Besides, the texts analysed in the aforementioned studies were presidential speeches. There are rare efforts to analyse speeches of state governors and other political icons at the grassroots level. Such speeches are very significant because each state has its peculiar structure, economic and sociopolitical challenges. Thus, this study is a worthwhile one as it seeks to fill the lacuna by taking the appraisal theory as theoretical framework to evaluate the attitude of Dr. Kayode Fayemi in his 2018 inauguration speech as governor of Ekiti state in Nigeria.

\subsection{Appraisal Theory}

Appraisal theory is a theory within the Systemic Functional Grammar. It is a development and an extension of interpersonal metafunction of Halliday's Systemic Functional Linguistics. Systemic functional Linguistics (SFL) recognises three modes of meaning- Textual, Ideational and interpersonal - which are simultaneously attested in any given text or utterances. Ideational resources are concerned with construing experience: what's going on, including who's doing what to whom, where, when, why and how and the logical relation of one going-on to another. Interpersonal resources are concerned with negotiating social relations: how people are interacting, including the feelings they try to share. Textual resources are concerned with information flow: the ways in which ideational and interpersonal meanings are distributed in waves of semiosis, including interconnections among waves and between language and attendant modalities. (Halliday \& Mattiessan 2004, Thompson 2004, Martins \& White 2005)

Appraisal therefore develops and extends the SFL account of the interpersonal by attending to three axes along which the speaker's/writer's intersubjective stance may vary. According to Thompson (2004:75) appraisal can simply be defined as 'the indication of whether the speaker thinks that something (a person, thing, action, event, situation, idea, etc) is good or bad". To Martins and White, Appraisal is concerned with the interpersonal in language, with the subjective presence of writers/speakers in texts as they adopt stances towards both the material they present and those with whom they communicate. It is concerned with how writers/speakers approve and disapprove, enthuse and abhor, applaud and criticise, and with how they position their readers/listeners to do likewise (Martins \& White 2005:1)

Appraisal itself is regionalised as three interacting domains - 'attitude', 'engagement' and 'graduation'. Attitude is concerned with our feelings, including emotional reactions, judgments of behaviour and evaluation of things. Engagement deals with sourcing attitudes and the play of voices around opinions in discourse. engagement refers to the set of resources drawn upon by speakers for introducing "additional voices into a discourse, via projection, modalisation or concession" Graduation attends to grading phenomena whereby feelings are amplified and categories blurred. Graduations are grammatical and lexical resources we use to "say how strongly we feel about someone or something" (Martin \& Rose, 2003). Meanwhile our concentration in this study is on attitude since our analysis shall be basically on the attitudinal meaning of the data. Attitude refers to the resources used to negotiate feelings, judge people's character and behaviour, and evaluate the worth of things. Attitude is itself divided into three regions of feeling, 'affect', 'judgment' and 'appreciation' We shall here look into the resources of Attitude in details.

\subsubsection{Affect}

Affect is concerned with registering positive and negative feelings: do we feel happy or sad, confident or anxious, interested or bored? (Martin and White 2005). According to Souza (2013), the subsystem of affect concerns linguistic resources speakers utilizes for expressing their feelings in terms of their emotional states and/or responses to some emotional trigger. In his contribution Martin (2000) explains that affectual meanings can be construed as positive or negative feelings that can be graded along a cline of low, median, and high non-discrete lexicalized intensity values (e.g. like - love - adore; dislike - hate - detest)

The system of affect is categorised into three major variables, namely un/happiness, in/security, and dis/satisfaction. Martin (2000) explains that "The un/happiness variable", "covers emotions concerned with 'affairs of the 
heart' - sadness, anger, happiness, and love"; The second variable of the affect system, dis/satisfaction, is concerned with what he terms 'telos' - the pursuit of goals - and involves emotions related to ennui, displeasure, curiosity, and respect. The third variable of the affect system, in/security, involves emotions concerned with 'ecosocial well-being' - anxiety, fear, confidence, and trust.

\subsubsection{Judgment}

According to Martin and White (2005), judgment is the region of meaning construing our attitudes to people and the way they behave - their character (how they measure up). Judgment resources refer to how speakers evaluate social behaviour in terms of socially established sets of moral, legal, and personal norms. As with resources for construing affect, judgment assessments can take positive and negative values. Explaining further, Martin (2000, p. 155) proposes that judgmental values can be thought of as "the institutionalization of feeling, in the context of proposals (norms about how people should and shouldn't behave)". In general terms judgments can be divided into two categories and they are those dealing with 'social esteem' and those oriented to 'social sanction'. (Martin and White 2005). Making reference to Eggins and Slade 1997, Martin and White 2005 submit that Judgments of esteem have to do with 'normality' (how unusual someone is), 'capacity' (how capable they are) and 'tenacity' (how resolute they are); judgments of sanction have to do with 'veracity' (how truthful someone is) and 'propriety' (how ethical someone is). Social esteem tends to be policed in the oral culture, through chat, gossip, jokes and stories of various kinds - with humour often having a critical role to play. (Eggins \& Slade 1997).

Judgments of social sanction encompass evaluative resources for assessing human behaviour by reference to a society's system of moral and legal norms. Social sanction is more often codified in writing, as edicts, decrees, rules, regulations and laws about how to behave as surveiled by church and state - with penalties and punishments as levers against those not complying with the code. Sharing values in this area underpins civic duty and religious observances. Martin $(1997,2000)$ organizes the sub-system of social sanction around two variables: propriety and veracity.

Judgments of propriety encompass resources for evaluating behaviour in terms of what is considered ethical or unethical by a particular community. In other words, values of propriety concern the social sphere of right-versus-wrong or goodversus-evil behaviour, which most societies tend to punish with sanctions enforced by law.

Judgments of veracity on the other hand are concerned with evaluations for assessing behaviour that pertains to the moral domains of sincerity and honesty. That is, judgments of veracity are assessments we use to express how truthful and honest we think someone is.

\subsection{Judgments of Social Esteem}

Judgments of social esteem are concerned with evaluations that may enhance or damage a person's image before his/her community, but which do not entail legal or moral consequences. Social esteem values are further sub-classified into three variables: normality, capacity, and tenacity,

- Judgments of normality refer to resources for evaluating how usual someone is.

- Judgments of capacity refer to resources we utilize to evaluate someone's skill, strength, and/or aptitude for carrying out certain social tasks

- Judgments of tenacity, as the name suggests, are attitudinal meanings we utilize to assess someone's determination to accomplish a particular piece of work.

\subsubsection{Appreciation}

Appreciations are interpersonal resources for expressing positive and negative evaluations of objects, texts, entities, processes, and natural phenomena. In general terms appreciations can be divided into our 'reactions' to things (do they catch our attention; do they please us?), their 'composition' (balance and complexity), and their 'value' (how innovative, authentic, timely, etc.). (Martin and White 2005).

\subsubsection{Purpose of Study}

This study aims to provide an exploration of the attitudinal choices and meaning in the inauguration speech of John Kayode Fayemi on October, 2018. The study will specifically:

- Carry out the analysis of attitude and its subsystems of affect, judgment, and appreciation in the speech

- Analyse the polarity of the attitudinal choices (i.e. whether they carry negative values, or a positive one)

- Find out how attitude is inscribed and invoked in the speech through the lexical and grammatical choices made by the speaker.

\section{Methodology}

The text for analysis in this study is the inauguration speech of John Kayode Fayemi on October, 2018 as the governor of Ekiti state, Nigeria after a battle-like election. The speech was broken down into clauses and the clauses with attitudinal meaning were identified. For space and time constraints, the clause by clause analysis of the speech cannot be presented here but the summary of the distribution of the attitudinal choices and strategies of the speech is presented in both quantitative and qualitative terms with samples drawn from the text. 


\section{Data Analysis}

\subsection{Analysis of Affect in the speech}

As mentioned earlier, values of affect refer to the construal of feelings in relation to one's emotional states, dispositions, and/or responses to some emotional trigger. The speaker uses the resource of Affect to present himself in certain emotional lights and create solidarity between himself and the people of Ekiti by making them to share his feelings about some major issues. It is worthy of note that all the three major variables of affect, namely Happiness, Security and Satisfaction are realised in the speech both explicitly and implicitly at both negative and positive end of the cline:

\subsubsection{Happiness/Unhappiness}

Fayemi, through the evaluative resource of affect expressed his happiness on the occasion of his inauguration as governor for the second time:

- It is my honour to stand before you today haven taken the oath of office as Governor of the Land of Honour, Ekiti State just moments ago

- Our most high God who rules the affairs of humankind, has so determined that I should have the rare honour of assuming this office for the second time, to the glory of His name

- I am truly grateful to the people of Ekiti for being the instruments...

\subsubsection{Security/Insecurity}

Security is evoked in the poem that the speaker uses as the opening of his speech:

- This land is ours; with all its glory, beauty, danger and chaos

- This land is ours, and we cling to it; even as we see the blood on the lips of the vultures who prod and peck at our throats, so they can suck even more blood;

Personalising the land as ours is an expression of positive feeling of security even though there had been some political crisis in the past that seemed to have alienated the speaker as true son of the land.

\subsubsection{Satisfaction/Dissatisfaction}

In the extract below, the speaker uses positive affectual meaning to express his satisfaction with the patriots who fought for the creation of the state;

- I must also salute our patriots of more recent years who worked hard to ensure we can have our own State within our great country Nigeria

- I also know that they would be particularly proud that we are all in this place symbolically called Ekiti Parapo Pavilion, which to the glory of God was one of the projects I inaugurated as I left office in October 2014

- The instantiation of satisfaction is also found in the extract below as the speaker tries to make the people get satisfied with his choice as the governor that everyone can be proud of:

- Ekiti Kete, today, rejoice. For once again you can be proud to be called a son or daughter of Ekiti. You can be proud that Ekiti is once again known as the Land of Honour, in truth and in deed

\subsection{Analysis of Judgment in the Speech}

Judgment resources refer to how speakers evaluate social behaviour in terms of socially established sets of moral, legal, and personal norms (Souza 2006). The Judgment assessment of the speaker takes both positive and negative value. Martin $(1997,2000)$ classifies the system of judgment into two categories: social sanction and social esteem. The former is categories of normality, capacity and tenacity, and the latter is categories of veracity and propriety. All these are greatly realised in the speech as the speaker tries to condemn, praise and criticise certain persons, events and phenomenon in the state. From the table 2 Above, Judgment as an aspect of attitudinal meaning has the highest frequency because the speaker as a politician has to appraise all the sectors of the government as well as the activities of the previous administration

\subsection{Judgments of Social Sanction}

Explicitly negative social sanction judgment, "propriety was used by the speaker to condemn immoral activities of the immediate past administration:

- This land is ours; and it shall be free.

Even as we see the blood on the lips of the vultures who prod and peck at our throats, so they can suck even more blood; This is judgment evoked. The speaker described the state (land) has been under political bondage and must be set free. Also, the speaker also negatively represented the previous political administration as a product of deceit and a mistake that must not be repeated.

- $\quad$...to work together to ensure that never again shall we be deceived into making such a grievous mistake that has set us back so steeply on the development curve.

Also, through the use of lexical metaphor in the following extracts, the speaker evoked a negative attitude of judgment of social sanction propriety:

- it also signals the end of an era, or more appropriately, the end of an error

The administration of his predecessor was regarded as an error which should not have come at all. He passes this judgment on the past administration based on the mis-rule and many other acts of the formal governor (Ayodele Fayose) which were regarded as socially unacceptable. In the extract below, the speaker uses the metaphor of wilderness 
experience to evaluate the experience of Ekiti people under the government of the former governor-Ayodele Fayose- in the last four years.

- Without a doubt, Ekiti has been through a horrible wilderness experience in the past four years.

In the following extract, the use of some negative adjectives to evaluate the reputation of the state as projected by the lifestyle and activities of the formal governor, Ayodele Fayose in Ekiti state. By moral standard he regards the lifestyle of the formal governor as unacceptable:

- Our reputation as a people has been sullied and we have become the butt of jokes due to the crass ineptitude, loquacious ignorance, and ravenous corruption masquerading as governance in our State during this past administration

Positive social sanction Judgment Propriety was used by the speaker to express the vision of his administration; He presents his agenda and ideological stance of governance through the resources of judgment as found in the extracts below:

- These are the same values that have been eroded in recent years, which we seek to restore

- My vision for our great State is that this is a place where people can thrive and live their lives in dignity. A place where workers do not labour in vain. A place where our young people do not roam the streets looking for jobs that are not there, a place where people are not so hungry, they resort to pilfering food to survive. A place where the cycle of generational poverty can be broken, and in which our elderly can reap the fruits of their labours over their children. A place where people are safe, healthy and prosperous.

In the extract below, the speaker uses both positive and negative judgment to condemn the current situation of things and as well present the way forward:

- Today, as we have reclaimed our land, we are now at the cusp of charting the course of sustainable development out of the quagmire that we find ourselves in.

Judgments of veracity on the other hand are concerned with evaluations for assessing behaviour that pertains to the moral domains of sincerity and honesty. That is, judgments of veracity are assessments we use to express how truthful and honest we think someone is. Using this resource, the speaker describes the previous administration as dishonest and insincere in handling the economic resources of the state in the extract below:

- Independently verifiable preliminary findings indicate that we have been plunged into a debt abyss of over N170billion, with commitments to innumerable white elephant projects, an average of 8 months salaries owed across government entities, and many state assets unaccounted for.

\subsection{Judgment of Social Esteem}

Social esteem involves admiration and criticism, typically without legal implications. It is concerned with evaluations that may enhance or damage a person's image. Social esteem values are further sub-classified into three variables: normality, capacity, and tenacity. All these are instantiated in the speech but tenacity has the highest number of instantiation while normality is slightly attested in the speech.

\subsubsection{Normality}

Normality is a resource for evaluating how fashionable or special a thing is. In the speech, the speaker uses the resource of normality to appraise the significance of his inauguration as the governor to the history of the state.

- As much as today marks the beginning of a new phase in our history as a people

\subsubsection{Capacity}

Capacity is a resource for evaluating skill, strength, and aptitude for carrying out certain social tasks; the speaker through the resource of capacity gives his assessment of who should be involved in governance:

- $\quad$... but the reins of leadership in Ekiti State must never again be allowed to fall into the hands of those who do not understand what governance or development is all about.

- $\quad$ Only a healthy and enlightened people can drive the sustainable development we want to see in Ekiti State

- $\quad$...as Ekiti people we should be committed to using our brilliant minds to promote sustainable development

- The light of knowledge and intellectualism that we are known for, which illuminates our minds and reflects in the good character and pristine values we hold dear

- He uses capacity as a resource to praise and admire the resourcefulness of Ekiti citizens in all field of human endeavour as Ekiti is accorded with the name 'Fountain of Knowledge'.

- $\quad$ Ekiti State is known as the Fountain of Knowledge. Our people love, seek, and celebrate knowledge. We arguably have the highest number of professors and academic pioneers per capita in Nigeria. We also have many of our citizens who are leading lights in every field of human endeavour as well as those who are at the frontiers of research in the academia and scholastic practice all over the world

- Another instantiation of capacity in the speech is seen in the extract below where he positively judged those who will work with him as competent. This is inscribed through the use of positive adjectives and relational attributes that are infused with attitude:

- You would find in this administration a competent, accountable and willing partner, and you will appreciate that our governance objectives are well aligned to global development priorities as enshrined in such instruments as the Sustainable Development Goals

\subsubsection{Tenacity}


Tenacity is an attitudinal resource to assess someone's determination to accomplish a particular piece of work. This resource was used to present his determination to turn the state around in all ramifications;

- We will ensure that within one hundred days from today, Ekiti Kete will know the true position of things, in keeping with our ethos of transparency and accountability in governance.

- As we assume office, it is our duty, and we will live up to it, to ensure we thoroughly review, document, and widely disseminate the present state of affairs so that all and sundry can know what has become of our commonwealth

- Tenacity is also used to appraise the founding fathers of the state in the extract below:

- I must start by specially paying homage to those that came before us and upon whose labours our generation is building upon; our forebears of ages past who bequeathed to us a rich history of honour and dignity; who bound together as one indivisible Ekiti confederacy, and fought wars to liberate us from external forces that sought to subjugate us. They taught us that only in fighting together can we truly win. I am certain that these ancestors of ours who we have learnt about in our history books, and from the oral traditions of our griots, are similarly assembled in the great beyond today as a great cloud of witnesses, cheering us on as we embark on this journey set before us

\subsection{Analysis of Appreciation}

Appreciations are interpersonal resources for expressing positive and negative evaluations of objects, texts, entities, processes, and natural phenomena. (Souza 2006). Martin $(1997,2000)$ organizes the system of appreciation around three categories: reaction, composition, and evaluation as earlier mentioned. Through the resources of appreciation, the speaker evaluates every sector of the state as well as the natural resources the state is endowed with.

\subsubsection{Reaction}

Evaluations of reaction are expressions of our liking or disliking of the objects, entities, and phenomena under our consideration (Souza 2006). In this speech the speaker uses negative evaluation of reaction to assess the critical sector of Ekiti State under the last administration. He expresses his detest for the way each sector was run by juxtaposing it with what should be. Examples are found in the following extracts:

- Never again should we give up free and qualitative education for herculean fees and taxes levied on our school children; never again should we give up free healthcare and functional hospitals for a total neglect of the health sector; never again should we give up integrated infrastructure development for bridges that lead nowhere; never again should we give up a burgeoning tourism sector and a revitalised Ikogosi for decrepit structures now overrun by reptiles; never again should we give up the peace and unity of our State for increased crime rates and general insecurity; never again should we give up transparent and accountable governance, with the requisite checks and balances of independent Judicial and Legislative arms of government, for draconian one-man shows; never again should we give up our reputation as a honourable and knowledgeable people, to be known as apostles of stomach infrastructure.

- In the above extract, the speaker shows his negative reaction to the way each sector was run by the last administration with the use of the negative mood adjunct and the modality: Never again should we give up.

- More of negative reaction is found in the following extracts:

- In order to further advance an economic and industrial revolution in Ekiti State, and in furtherance of our commitment to job and wealth creation, we will revisit the commercial and technical viability of abandoned projects and schemes in the State with a view to reactivating them

- To this end, my administration will resuscitate the Ekiti Knowledge Zone which was established during my first term in office.

- These are the same values that have been eroded in recent years, which we seek to restore

- In the above extracts, his dislike for the state of the projects are clearly shown through his lexical choices such as "reactivating", "restore" and "resuscitate".

\subsubsection{Composition}

Composition is concerned with the way we perceive the relationship of proportion between the different parts that compose an entity

- Ekiti is essentially an agrarian society with soil properties conducive for growing a wide variety of crops

- Ekiti State is known as the Fountain of Knowledge. Our people love, seek, and celebrate knowledge. We arguably have the highest number of professors and academic pioneers per capita in Nigeria

- The light of knowledge and intellectualism that we are known for, which illuminates our minds and reflects in the good character and pristine values we hold dear.

\subsubsection{Valuation}

Valuation assessments are resources speakers utilize for evaluating their social significance in relation to culturally or ideologically established conventions. In other words, valuations are assessments that express the social significance that an object/entity has for members of a particular community

- For once again you can be proud to be called a son or daughter of Ekiti

- Let us build the Ekiti of our dreams, a land we can be proud to pass on to our descendants.

\section{Discussion}


Attitude in the text are both invoked and inscribed. Invoked attitude is implicitly and indirectly marked and needs inference from the text and the political context of the state while inscribed attitude is explicitly and conspicuously marked in text and discoverable. The table below shows the distribution of the strategy of attitudinal choices in the text:

\begin{tabular}{|c|c|c|}
\hline Strategy & Inscribed & Invoked \\
\hline Instances & 55 & 52 \\
\hline Percentage & 51.4 & 48.6 \\
\hline
\end{tabular}

Table 1: Distribution of Attitudinal Choices in Fayemi's Inauguration Speech

The close range between the invoked and inscribed attitude in the speech shows that the speaker carefully chose his words and expressions to reveal his attitudinal stance.

Attitude is inscribed in the text through the use of some adjectives and other evaluative lexical items such as process and attributes in relational clause that are infused with attitudinal meanings as well as pejorative names:

- We will rejoice and be glad in it. For today, we reclaim our land from the hands of those that have held us captive.

- I am certain that these ancestors of ours who we have learnt about in our history books, and from the oral traditions of our griots, are similarly assembled in the great beyond today as a great cloud of witnesses, cheering us on as we embark on this journey set before us

- I salute and honour you all and i thank you for the grand vision you had for our beloved state. I warmly greet all ekiti sons and daughters at home and abroad

- I thank you all for your perseverance and service to our great state

- Evoked attitude is realised in the text through the use of lexical metaphor and some other local expressions that can only be explicated by resorting to the socio-political context that surround the speech.

- Ekiti has been through a horrible wilderness experience in the past four years. Our reputation as a people has been sullied and we have become the butt of jokes due to the crass ineptitude, loquacious ignorance, and ravenous corruption masquerading as governance in our state during this past administration.

- ... never again should we give up integrated infrastructure development for bridges that lead nowhere

Generally, the attitudinal choices of Fayemi in the speech across the three subsystems of Affect, Judgment and Appreciation are both positive and negative in evaluating the state of things in Ekiti. The table below shows the frequency of the polarity of the attitudinal choices of Fayemi in the speech.

\begin{tabular}{|c|c|c|}
\hline Polarity & Positive & Negative \\
\hline instances & 49 & 58 \\
\hline percentage & 45.7 & 54.2 \\
\hline
\end{tabular}

Table 2: The Distribution of Polarity of Attitude in the Speech

The table above shows that negative attitudinal values in the speech are more than the positive. This shows that there are more numerous negative realities in the state the governor has to react to and make comments about.

The speech is however, full of attitudinal meanings that reflect the speaker's position on and reaction to the economic and socio-political situation of the state as well as the experience of the citizens in the past four years. Attitude in the speech are deployed in the construal of three main semantic domains, of affect, judgment, and appreciation. The table below presents the percentage distribution of the attitudinal stances of Fayemi in the speech

\begin{tabular}{|c|c|c|c|}
\hline Type & Affect & Judgment & Appreciation \\
\hline Instances & 37 & 49 & 21 \\
\hline Percentage & 34.5 & 45.7 & 19.6 \\
\hline
\end{tabular}

Table 3: Distribution of Attitudinal Stances in Fayemi's Inauguration Speech

Out of 107 clauses of the speech analysed to be carrying attitudinal meaning, 37 representing $34.5 \%$ carry affectual meaning; 49 representing 45.7\% construe judgment while the remaining 21 representing $19.6 \%$ show appreciation. From the table above, it is obvious that Judgment has the highest number of instances in the speech. This may be due to the fact that the speaker was using the speech to comment on and appraise every sector of the state and as an incoming governor who had one time been governor of the state, he needs to comment on the realities on ground. Attitude (Affect, Judgment and Appreciation) in the speech can be judged as an effective strategy by Fayemi for evaluating the socio-economic reality of Ekiti state and the performance of previous government; positioning his audience ( Ekiti people) and for negotiating solidarity with them by making them to share his feelings as well as appreciating the human capital resources of the state. This actually corroborates Martin (2000, p. 172) who posits that when the audience shares the speakers' feelings, "a kind of bonding occurs, where they are not so prepared, the effect is alienating".

\section{Conclusion}

This study is an attempt to analyse the evaluative language in the inauguration speech of Governor John Kayode Fayemi as an example of political speech in Nigeria. The study has so far revealed that political speeches of this nature are imbued with attitudinal meanings establishing interpersonal relation between the speaker and both the audience and some other contextual realities. This affirms the submission of Martin and white (2005) that Attitudinal meanings tend to 
spread out and colour a phase of discourse as speakers and writers take up a stance oriented to affect, judgment or appreciation.

\section{References}

i. Ademilokun, M. (2015). Aspects of attitudinal meaning in Nigerian President Muhammadu

a. Buhari's inauguration speech: an appraisal analysis. The African Symposium 3(15)

ii. Ayeomoni, 0. \& Akinkuolere, 0. (2012). A pragmatic analysis of victory and inaugural speeches of President Umaru Musa Yar'Adua. Theory and Practice in Language Studies, 2 (3), 461-468.

iii. Ayoola, M.O. (2015). A systemic functional grammatical analysis of political advertisements in selected Nigerian newspapers. Unpublished. PhD thesis submitted to the department of English, University of Ilorin.

iv. Eggins, S. and Slade, D. (1997). Analysing casual conversation. London: Cassell.

v. Halliday M, Matthiessen C. (2004). An introduction to functional grammar. (3rd. ed.)

a. London: Arnold. 480 pp.

vi. Martin, J. R. (1997). Analysing genre: functional parameters. In: F. Christie \& J. R. Martin. $\quad$ Eds. Genre and institutions: social processes in the workplace and school. London: Cassell.

vii. Martin, J.R. (2000). Beyond exchange: appraisal systems in English. In: S. Hunston \& G. Thompson. Eds. Evaluation in Text: authorial stance and the construction of discourse. Oxford: Oxford University Press.

viii. Martin, J. R. \& Rose.D. (2003). Working with Discourse: meaning beyond the clause. London: Continuum.

ix. Martin, J. R. and White, P.R.R. (2005). The Language of Evaluation: appraisal in English. London: Palgrave.

x. Opeibi B O (2006). Political marketing or political "macheting"? a study of negative campaigning in Nigerian political discourse. From <http://www.inst.at/ trans/16Nr/01_4/Opeibi16.html>. (Accessed on 21st March, 2010).

xi. Souza, A.A. (2006). The construal of interpersonal meanings in the discourse of national anthems: An appraisal analysis. Proceedings of the 33rd International Systemic Functional Congress,531-550.

xii. Thompson, Geoff (2005). Introducing functional grammar. London: Edward Arnold

xiii. Thorne, S. (2008). Mastering advanced English language. New York. Palgrave 